\title{
A emancipação feminina no Iluminismo: um diálogo crítico entre Wollstonecraft e Rousseau
}

\author{
Women's emancipation in Enlightenment: a critical dialogue \\ between Wollstonecraft and Rousseau
}

Oswaldo Pereira de Lima Junior ${ }^{1}$

Luana Cristina da Silva Dantas ${ }^{2}$

\begin{abstract}
RESUMO
O presente artigo tem por finalidade contextualizar a obra de Mary Wollstonecraft, em especial a "Reivindicação dos Direitos da Mulher", escrita em 1792, com o convencional pensamento iluminista de seu tempo, tomando como ponto de referência a exclusão ou o tratamento diferenciado da mulher percebida em certas passagens de "Emilio ou da Educação" de JeanJacques Rousseau. Explora, ainda, alguns outros "luminares" da época, como Charles-Maurice e Immanuel Kant, bem como outra "protofeminista" de seu tempo, Olympe de Gouges, despontando a conclusão de que a obra de Rousseau alija a mulher em três escolhidos aspectos: a educação, a pessoalização e a cidadania. A pesquisa se fez por intermédio do método qualitativo, procedendo-se a análise compreensiva do tempo e das ideias dos autores, imiscuindo-se na bibliografia escolhida da autora e de seu contraposto, refazendo as percepções de ambos os autores sobre a Declaração em função do Homem e da Mulher, com o fito de demonstrar que há diferença de tratamento entre ambos os sexos sem que haja, contudo, justificativa ética ou filosófica. O estudo teve por mote, portanto, constituir recortada análise e observação das obras citadas intencionando compreender e reconstituir determinados fatos sociais presentes na discussão entre Wollstonecraft e Rousseau para compreender a presença de uma agenda progressiva nas ideias da autora e, na medida do possível, fazer um breve cotejo de suas palavras com os percalços que a mulher ainda enfrenta na sociedade contemporânea, especialmente quanto à sua educação, à conquista da cidadania e sua completa pessoalização.
\end{abstract}

\section{PALAVRAS-CHAVE:}

Iluminismo; Rousseau; Igualdade de Gênero; Wollstonecraft.

\footnotetext{
${ }^{1}$ Doutor em Direito pela Universidade Estácio de Sá/RJ (UNESA). Mestre em Biodireito, Ética e Cidadania pelo Centro Universitário Salesiano de São Paulo (UNISAL). Professor e Vice Coordenador do Curso de Direito da Universidade Federal do Rio Grande do Norte (UFRN). Coordenador do Projeto de Pesquisa "Entre o biológico e o humano: pessoalização e conflitos parentais diante da gestação e do status moral do nascituro" e do Projeto de Extensão “(En)Cine Direito”. Coordenador do Grupo de Pesquisa Direitos Fundamentais e Desenvolvimento Social da UFRN. Pesquisador do Grupo de Pesquisa Pesquisa JUstiça, DIreito e TEcnologia - JUDITE da Universidade Estadual da Paraíba (UEPB) Campina Grande/PB. ORCID: https://orcid.org/00000002-0019-1391. CV Lattes: http://lattes.cnpq.br/2129410182219103. E-mail: oswaldolimajr@ gmail.com.

${ }^{2}$ Acadêmica do $9 .^{\circ}$ período do Curso de Direito da Universidade Federal do Rio Grande do Norte (UFRN), pesquisadora do Grupo de Pesquisa Direitos Fundamentais e Desenvolvimento Social, do Projeto de Pesquisa "Entre o biológico e o humano: pessoalização e conflitos parentais diante da gestação e do status moral do nascituro" e do Projeto de Extensão "(En)Cine Direito", todos da UFRN, Campus de Caicó/RN. ORCID: https://orcid.org/0000-0003-4867-5616. CV Lattes: http://lattes.cnpq.br/2129410182219103. E-mail: http://lattes.cnpq.br/8522812971613232.
} 


\begin{abstract}
This article aims to contextualize the work of Mary Wollstonecraft, in particular "Claim of women's rights", written in 1792, with the conventional Enlightenment thought of her time, taking as reference the exclusion or differentiated treatment of the woman perceived in certain passages of "Emilio or Education" by Jean-Jacques Rousseau. It also explores some other "illuminists", such as Charles-Maurice and Immanuel Kant, as well an another "protofeminist" of her time, Olympe de Gouges, raising the conclusion that Rousseau's work will excludes woman in three aspects: education, personalization and citizenship. The research was carried out through the qualitative method, performing a comprehensive analysis about the authors' time and ideas, impending on the author's chosen bibliography as well on the bibliography of her counterpart, remaking the perceptions of both about the Declaration according to Man and Woman, with the purpose of demonstrating that there is a difference in treatment between both sexes, although there's no ethical or philosophical justification. The study aimed to compose a focused analysis and observation about authors' works intending to understand and reconstitute certain social facts present in the discussion between Wollstonecraft and Rousseau and to see the presence of a progressive agenda in the author's ideas and, as far as possible, to make a brief comparison of her words with the mishaps that women still face in contemporary society, especially regarding education, citizenship and complete personalization.
\end{abstract}

\title{
KEYWORDS:
}

Enlightenment; Rousseau; Gender Equality; Wollstonecraft.

\section{INTRODUÇÃO}

O presente artigo tem por mote a análise de partes da obra Reivindicação dos Direitos da Mulher, escrita por Mary Wollstonecraft em 1792 e Emilio ou da Educação, de Jean-Jacques Rousseau, de 1762. A ideia principal é mostrar que, em que pese a distância temporal entre as obras, que se distam em trinta anos, e o fato de que Rousseau já havia morrido no tempo de seu lançamento, a autora procede uma interessante afronta e quase uma interlocução com o filósofo, expondo sua obra a críticas que podem ser vistas como precursoras daquilo que seria futuramente denominado como feminismo.

"Uma figura revolucionária em uma época revolucionária [...]”, Wollstonecraft translitera interessante e imperioso apelo liberal não apenas aos homens, como se percebe nas obras - masculinas - de seu tempo, mas à mulher, peticionando direitos como a possibilidade de ser educada para além do papel social de esposa, contestando o ideal fracionário de igualdade 
de seu tempo, abordando, ainda,“[...] questões relativas aos princípios da autoridade política, tirania, liberdade, classe, sexo, casamento, criação infantil, propriedade, preconceito, razão, sentimentalismo, promessas, suicídio, para mencionar apenas alguns"”3 (JOHNSON, 2002, p. $1)$.

Preliminarmente, portanto, coloca-se em pauta argumentos concernentes a problemáticas de gênero que versejam a condição da mulher na Idade das Luzes, na qual os ideais de liberdade, igualdade e fraternidade consubstanciavam a escrita das Cartas Constitucionais. Os temas são abordados, de outra feita, de modo historicamente situados sob a fala de Wollstonecraft que, contrapondo-se especialmente a Rousseau e sua obra Emilio ou da Educação, destaca que a mulher havia sido excluída da cidadania pela recém-promulgada Constituição Francesa (1791), não possuindo direito ao voto, à participação política e ao acesso à educação formal. A tutela feminina permanecera vinculada à autoridade masculina: passava da tutela paternal para marital, e tão-somente isso.

Em escala crescente, o presente artigo trata, a princípio, de delinear uma breve biografia de Mary Wollstonecraft, visando perceber a sua própria formação como mulher consciente de seus direitos. Sequencialmente, faz-se, ainda, um pequeno retrato da Europa oitocentista, mostrando o casulo de ideias luminares que gerava importantes ideais de direitos humanos mas que, em contrapartida, criava uma situação de injustiça institucional em desfavor ao feminino, tomando em seu bojo a perspectiva naturalístico-determinista de que, à mulher, apenas estava reservada a incumbência dos assuntos do lar, de modo a perpetrar o bom funcionamento social através da gestão dos assuntos domésticos.

Após, a análise se faz sobre a contraposição de ideias entre o mainstream iluminista oitocentista, no presente recorte metodológico representado por Rousseau, e a crítica enfática de Wollstonecraft. Enfatiza-se, então, três aspectos que a autora destaca como sendo explícitos na segregação feminina, a saber: a) a educação; b) a pessoalidade; e c) a cidadania. A autora, então, procura, historicamente, conformar a mulher aos padrões de seu tempo, denunciando o equívoco das exclusões que percebe, utilizando-se, como já adiantado, de especial

\footnotetext{
${ }^{3}$ Tradução livre dos autores de "A revolutionary figure in a revolutionary time, she took up and lived out not only the liberal call for women's educational and moral equality, but also virtually all of the other related, violently contested questions of the 1790s- questions pertaining to the principles of political authority, tyranny, liberty, class, sex, marriage, childrearing, property, prejudice, reason, sentimentality, promises, suicide, to mention only a few".
} 
argumentação em face das obras "Emilio ou da Educação", "Do Contrato Social" e "Discurso sobre a origem e os fundamentos da desigualdade entre os homens" para denunciar as assimetrias e desequilíbrios nas relações entre os sexos. Pleiteia a inserção da mulher no estatuto político-constitucional nascente, conclamando a efetividade do processo de aquisição de sua personalidade jurídica para que, efetivamente, se tornassem "sujeitas" de direito, titulares de suas vidas e das relações jurídicas, promovendo, por conseguinte, os preceitos iluministas de igualdade humana que lhes fora negado.

Aprofundando-se a discussão, perquire-se acerca da investigação moral sobre o direito (humano) da mulher em dispor de sua vida como um projeto biográfico pessoal, causando o fortalecimento do senso moral e jurídico de sua autonomia pessoal. A filósofa pondera que há certa mentalidade social, outorgada pelas instituições do Estado, que impede a mulher de atingir sua "maioridade", de desfrutar de real autonomia de vida e, portanto, de viver integralmente sua condição de pessoa humana. Nessa dimensão, problematiza os traços patriarcais de seu tempo, esboça a forma como a mulher fora cerceada de emancipar sua própria existência pela imposição de um modelo de vida pré-estabelecido, tornando-se estéril em seu próprio universo. Ademais, numa ordem mais complexa, coloca em discussão o dever ético de reconhecimento das mulheres enquanto detentoras e sujeitas únicas de suas vidas. A liberdade, a autonomia e a razão, cujo exercício era solapado às mulheres, são condicionantes indispensáveis à própria construção da humanidade do sujeito. Nessa contenda sobre o conceito de liberdade e autonomia pessoal, faz-se breve presença sobre o pensamento de Immanuel Kant em suas obras Fundamentação da Metafísica dos Costumes (1785) e em sua resposta à indagação $O$ que é o iluminismo? (1784).

O teor crítico da obra se mostra, em suma, mais complexo do que a primeira vista faz parecer, eis que as manifestações de Wollstonecraft, como bem salienta Johnson ${ }^{4}$ (2002, p. 1) vão além de um mero manual de educação da mulher, para assumir postura de manifesto de

\footnotetext{
${ }^{4}$ Johnson (2002, p .1) é incisiva ao afirmar que "Embora sua Reivindicação dos Direitos da Mulher (1792), por exemplo, a princípio tenha recebido críticas bastante respeitosas como um tratado sobre a educação feminina, após a Inglaterra e a França declararam guerra, a obra foi cada vez mais (e corretamente) lida sob o pano de fundo de suas agendas progressistas mais amplas em nome da liberdade". Tradução livre dos autores de: "Although her A Vindication of the Rights of Woman (1792), for example, at first received fairly respectful reviews as a tract on female education, after England and France declared war, it was increasingly (and correctly) read against the backdrop of its broader progressive agendas on behalf of liberty".
} 
jaez progressivo em favor de um agenda mais ampla sobre a liberdade (liberdade extensiva às mulheres, no caso).

O artigo faz uso da metodologia qualitativa através da análise compreensiva (interpretativa) estendida sobre o tempo da autora em recorte histórico-temporal e sobre, em especial, o pensamento de Rousseau, visando comprovar que há nas palavras do autor e, de maneira geral, dos autores iluministas de seu tempo, inegável alijamento sexista da mulher, decerto que não participam de modo autônomo do projeto iluminista, são tratadas como seres a serem tutelados, mais fortes no sentimento do que na razão, e por isso carentes de cuidados masculinos. O mote da pesquisa se desdobra, então na educação, na pessoalização e na cidadania da mulher como elementos em que Rousseau procede leitura marcadamente segregacionista e que, conforme se pauta ao longo do capítulo final, é veementemente contraposto e repreendido pela autora.

\section{CONTEXTUALIZANDO MARY WOLLSTONECRAFT COM O ILUMINISMO}

O Iluminismo, ou Esclarecimento, representa a ascensão, no pensamento ocidental, da razão sobre todas as matérias em que o conhecimento humano pudesse versar, em especial sobre os instintos naturais, sobre o mito e a religião, numa tentativa de extirpar folclores, conhecimentos sem base científicas e outros obscurantismos que não pudessem se adequar ao pensamento crítico e ao saber autônomo (IBER, 2012, p. 12). Rousseau (2006, p. 88) explicita, a exemplo, um dos grandes elementos revolucionários desse tempo, a Liberdade, expondo "As almas baixas não acreditam nos grandes homens; os vis escravos riem com ar burlesco da palavra liberdade"; tema que seria, ainda, muito caro a outros luminares, como Immanuel Kant (2007, p. 79) que centra toda seu projeto ético na humanidade como agente autônomo, isto é, livre para agir conforme a razão, para agir como aquilo que denomina "legislador no reino dos fins", “[...] como livre a respeito de todas as leis da natureza, obedecendo somente àquelas que ele mesmo se dá e segundo as quais as suas máximas podem pertencer a uma legislação universal (à qual ele simultaneamente se submete)". 
Ambos os luminares proclamam algo que já era caro à Wollstonecraft, a autonomia da vontade de uma pessoa como elemento construtor de sua própria dignidade e a intenção subsequente de mudar a sociedade com novos ideais. Kant (2007, p. 79) no ponto é direto "Autonomia é pois o fundamento da dignidade da natureza humana e de toda a natureza racional." No que se segue o pensamento de Wollstonecraft que percebia no seu tempo necessidades luminares que, todavia, se mostram contemporâneas, próprias da era atual, tais como "[...] a necessidade de as mulheres buscarem autonomia, seja financeira ou emocional, bem como a luta pelo direito das mulheres à educação formal transformadora” (ESTACHESKI; MEDEIROS, 2017, p. 376).

Os temas da liberdade e da mudança social se mostram centrais na obra da autora, mostrando sua característica igualmente iluminista, mas provocando novas reflexões, eis que pretende estender a liberdade e, de igual maneira, a igualdade, às mulheres também.

A breve biografia da autora servirá, portanto, para situá-la historicamente, determinando sua raiz ligada ao esclarecimento que vivia.

\subsection{Resumo Biográfico de Mary Wollstonecraft}

Wollstonecraft nasceu na primavera de 1759 em Spitalfields (Londres, Reino Unido). De acordo com Ferreira (2009, p. 21), nos idos do seu nascimento, sua família pertencia a uma classe social de médio poder aquisitivo. A estabilidade financeira familiar, todavia, transmutouse em pobreza devido aos abusos e desregramentos financeiros de seu pai, John Wollstonecraft. Segunda filha de sete irmãos, assistiu episódios recorrentes de violência doméstica sofridos por sua mãe, Elizabeth Dixon.

Com dezenove anos sai do lar paterno para trabalhar como governanta de uma senhora em Bath, mirando resgatar sua família dos maus negócios e das dívidas paternas. Até os vinte e sete anos trabalhou em vários empregos com a intenção de "ganhar a independência de seus pais, depois por necessidade de sustentar a si mesma, suas irmãs, irmãos e sua família estendida”. Ainda teve de retornar ao lar familiar para cuidar da mãe adoecida, com quem permaneceu por um ano, até a sua morte. Finalmente, alguma independência parece ter vindo 
com a fundação de uma escola em Islington (após, em Newington Green), da qual pôde dispor de um lugar e de renda para si, suas irmãs e, ainda, para uma amiga próxima, Frances Blood (BERGÈS, 2013, p. 3-4) ${ }^{5}$.

Aos vinte e oito anos, depois de ter ido trabalhar como governanta para uma família de aristocratas na Irlanda, retorna à Inglaterra e recebe o conselho do editor de seu primeiro livro a tentar viver da escrita, ao passo que lhe oferece, também, um cargo de escritora na Analitical Review. O fato de começar a tecer sua renda através da escrita não conduz, necessariamente, a autora à condição ímpar em seu tempo, decerto que muitas outras mulheres já proviam alguma renda da escrita, especialmente em livros sobre a educação e sobre as crianças, escrevendo, também, resenhas e novelas. Contudo, Wollstonecraft conseguira fazer disso um meio de vida perene, possuía um emprego em uma revista, não apenas era "[...] uma mulher vendendo manuscritos na esperança de ganhar um pouco de dinheiro. [...] Era escritora e jornalista, encarregada de críticas regulares"6 (BERGÈS, 2013, p. 3) e, notadamente, com rendimentos regulares também.

Em seus escritos, nota-se que a autora se preocupa em revelar que havia, nas relações interpessoais que a cercavam, claro enclausuramento da existência feminina - circunscrita unicamente ao ambiente doméstico, sem acesso à escolarização formal e à cidadania e, portanto, anulada-resilida em sua identidade e completude, incapaz de qualquer possibilidade de emancipação: “[...] contudo, os homens que, por seus escritos, mais têm se esforçado para domesticar as mulheres tratam de debilitar seus corpos e entorpecer suas mentes por meio de

\footnotetext{
5 Tradução, adaptada, dos autores de "Between the ages of nineteen and twenty-seven, Wollstonecraft took on a series of jobs, at first to gain independence from her parents, then out of necessity to support herself, her sisters, brothers and extended family. At the age of nineteen, she left home to work as a lady's companion in Bath, hoping to make enough money to rescue her family from her father's increasing debts. She came home after a little over a year to nurse her sick mother, and was with her until her death a year later. She then founded a school in Islington (and then in Newington Green) thereby creating a home and an income for herself, her sisters and her close friend Frances Blood. As this was not sufficient to pay for the debts she and her sisters accumulated through the failing books, to advise her in her readings, and to engage her in intellectual discussions about them. During her Yorkshire adolescence, it was her best friend Jane Arden's father, a philosopher by profession, who provided her with a library and guidance in her readings, and in her early twenties, the Revd and Mrs Clare in Hoxton, London, and the friend she met through them, Frances Blood, were responsible for much of her reading as well for her developing writing skills" (BERGÈS, 2013, p. 3-4).

6 Tradução livre dos autores de: "But Wollstonecraft was not, like many of the others, a woman peddling manuscripts in the hope of making a little money: she had a job. Johnson guaranteed her a decent income if she would take on commissions from him. She was a staff writer, and a journalist, in charge of regular reviews" (BERGÈS, 2013, p. 3).
} 
argumentos ditados por um apetite grosseiro, que a saciedade torna fastidioso" (WOLLSTONECRAFT, 2016, p. 88-89).

Em pouco tempo sua pena desvela romances, cartas, manifestos políticos, ensaios, tratados de direito e de pedagogia (...). Em 1792, publicou sua magnum opus "Reinvindicação dos Direitos da Mulher”, em resposta à recente Carta Constitucional francesa, promulgada em 1791, que, a despeito dos ideais de liberdade, igualdade e fraternidade apregoados em sua base principiológica, não incluíra as mulheres na categoria de cidadãs. Seu manifesto refutava, um-a-um, nomes como Jean-Jacques Rousseau, John Milton, John Gregory, Alexandre Pope, Thomas Day, David Hume e Charles-Maurice de Talleyrand-Périgord, filósofos que apesar de fundamentarem-se sobretudo no discurso da razão humana, reservavam à mulher lugares secundários e ínferos na sociedade:

Acusem-me de arrogância; ainda assim, declaro acreditar firmemente que todos os escritores que têm tratado do tema da educação e das maneiras femininas, desde Rousseau até o dr. Gregory, têm contribuído para tornar as mulheres mais artificiais e de caráter mais fraco do que elas realmente são; e, consequentemente, membros mais inúteis da sociedade (WOLLSTONECRAFT, 2016, p. 42).

Não obstante, ainda no tear de suas linhas revolucionárias, caminhando da poesia a textos científicos, cercou-se de nomes e teorias que ratificavam suas ideias, recorrendo a autores como Samuel Johnson, Francis Bacon, Voltaire e outros. Apenas para ilustrar sua ironia ilustrada e a oposição que fazia ao tratamento docilizado e caseiro da mulher, assevera:

"Certamente", diz lorde Bacon, "o homem é aparentado das bestas por seu corpo; e, se ele não for aparentado de Deus por seu espírito, ele é uma criatura vil e ignóbil!”. De fato, me parece que os homens agem de maneira muito pouco filosófica quando tentam assegurar a boa conduta das mulheres, tratando de mantê-las sempre em um estado infantil. (WOLLSTONECRAFT, 2016, p. 40).

A reconstrução da biografia da autora não pode ser feita separadamente ao desenvolvimento de algumas de suas ideias que, ao mesmo tempo que se adequam ao liberalismo nascente, possuem carga de indignação e de revolta. Se há indignação em excesso nas páginas da escritora, há também coragem e força desmedidas. A admiração que produz sua biografia reside na pungência de sua fala, quase solitária... Acha-se no percurso que escolheu para si, na contínua tomada de consciência acerca da injustiça, tão palpável, representada no papel desafortunado e historicamente destinado à mulher, bem como na compreensão da necessidade de luta pela igualdade entre os sexos, sobretudo tendo por ideário e mote o conceito 
de pessoa gestado no Século das Luzes. Esse espírito aparece na Carta a Talleyrand-Périgord, bispo de Autun:

É, então, um afeto por todo o gênero humano que faz minha pena escrever rapidamente para apoiar o que acredito ser a causa da virtude; e a mesma razão me leva a desejar de modo sincero ver a mulher em uma posição a partir da qual avance, em vez de ser refreada, para o progresso desses gloriosos princípios que dão substância à moralidade (WOLLSTONECRAFT, 2016, p. 19).

Sua biografia de autora, portanto, está recheada de questionamentos luminares acerca do porquê de a mulher ser excluída do projeto iluminista. Por que as mulheres deveriam ser infertilizadas, despidas de sua existência individual, sob a não extensão para si do medular argumento da Revolução Francesa: a Razão? ${ }^{7}$ As ideias da Iluminação deveriam irrigar atmosferas de utopias nas quais os "novos" direitos haviam de ser extensivos a toda a humanidade, e não somente aos homens brancos europeus. Movida por tais preceitos, parece escolher uma causa por qual lutar. Ela, mulher, a seu passo, no viver de suas experiências e opções de estudo, proibida de ocupar ambientes de educação formal tão fundamentais para o acesso ao conhecimento e, por extensão, exercício da razão, alcançou sua "maioridade” e passou a defender que todas as mulheres, em iguais condições que o homem, tivessem o direito e oportunidade de vir da sua menoridade à maioridade. Afinal, "que faz do homem o juiz exclusivo, se a mulher compartilha com ele o dom da razão?" (WOLLSTONECRAFT, 2016, p. 19).

Em 10 de setembro de 1797, com apenas trinta e oito anos, em Londres, Mary Wollstonecraft morria de febre puerperal, apenas dez dias depois de dar à luz sua segunda filha, Mary (Shelley), provavelmente de infecção por uso de equipamentos médicos não esterilizados (BERGÈS, 2013, p. 1). E seu tempo perde a escritora que antecipou, na época em que a biologia apenas dava seus primeiros passos em direção à revolução científica que os novos séculos lhe trariam, que a condição de esclarecimento não é conquistada pelos meandros da genética, que faz o humano dimorfisado em gêneros, mas através de sua capacidade moral, ou quiçá, furtando

\footnotetext{
${ }^{7}$ Rousseau, verbi gratia, é explícito ao afirmá-lo: "Quando a mulher se queixa da injusta desigualdade que o homem impõe, não tem razão; essa desigualdade não é uma instituição humana ou, pelo menos, obra do preconceito, e sim da razão: cabe a quem a natureza encarregou do cuidado dos filhos a responsabilidade disso perante o outro" (ROUSSEAU, 1999, p. 428). Em infeliz posicionamento uníssono a Rousseau, ainda mais marcante por ser já mais à frente no tempo, há de ser lembrar de Auguste Comte, para quem: "Toda mulher deve, pois, ser cuidadosamente preservada do trabalho exterior, a fim de poder preencher dignamente sua santa e natural missão. Voluntariamente encerrada no santuário doméstico, a mulher aí promove livremente o aperfeiçoamento moral de seu esposo e de seus filhos, cujas justas homenagens ela aí dignamente recebe” (2000, p. 278).
} 
de Kant (2001, p. 470) um pouco de sua fala, pelo valor - ou pela dignidade - próprio da pessoa humana como ser autônomo em si e por si.

\subsection{Um breve esboço da Europa Oitocentista: o século que gestou a vindicação dos Direitos da mulher}

O que significa estar na Europa à época de Mary Wollstonecraft?

Nas linhas de Hobsbawm (1996, p. 26), o "longo século XVIII” eclodiu em revoluções que fundaram a maior transformação da história humana, comparável aos remotos tempos, quando o homem inventou a agricultura e a metalurgia, a escrita, a cidade e o Estado. Tais revoluções transformaram, e continuam a transformar, a história global. Ao considerá-las, há de se distinguir cuidadosamente entre os seus resultados de longo alcance, que não podem ser limitados a qualquer estrutura social, organização política ou distribuição de poder e recursos internacionais, e suas consequências imediatas, captadas e sentidas pelas pessoas que as vivenciaram. Representam, sim, o capitólio de atores muito precisos "[...] não da 'indústria' como tal, mas da indústria capitalista; não da liberdade e da igualdade em geral, mas da classe média ou da sociedade 'burguesa' liberal; não da 'economia moderna' ou do 'Estado moderno', mas das economias e Estados em uma determinada região do mundo" (HOBSBAWM, 1996, p. 27).

No correr de tais séculos, dois movimentos social-filosóficos são especialmente marcantes para os contornos que se sucederam: o Renascimento, que, em curtas palavras, tentou ${ }^{8}$ desviar a teologia da posição central dos caminhos humanos para, em seu lugar, assentar a figura do Homem; e o Iluminismo, agente catalisador da revigoração-reinvenção de algumas

\footnotetext{
${ }^{8}$ Afirma-se "tentou" porque há uma aparente ruptura entre as estruturas científicas e as teológicas, mas, conforme salienta Damião (2018, p.22-23) essa pode ser uma premissa falsa: "Isto foi possível porque uma das premissas mais defendidas pelos historiadores da ciência, e corroborada por autores de outras áreas, é falsa: o Renascimento não marcou uma ruptura inconciliável entre ciência e religião, uma não se tornou o oposto da outra em termos epistemológicos, como o reducionismo historiográfico da modernidade positiva assumiu; pelo contrário, durante a renascença, ciência e religião caminharam lado a lado, inclusive esta foi fundamental para o desenvolvimento daquela durante os séculos da modernidade".
} 
das concepções de Justiça (de Justo) como elementos jurídicos atuantes sob a égide hegemônica da Razão?.

Analisando a filosofia como um discurso historicamente construído, Hegel professa a ideia de filosofia da história da filosofia (MARCONDES, 2005, p. 139), expondo que "Quem quiser descortinar o ponto central, deve buscá-lo no nexo essencial que liga os tempos aparentemente passados com o grau atualmente alcançado pela filosofia" (HEGEL, 2006, p. 13). Nesse contexto, é certo que a Europa vivia as viragens da modernidade ${ }^{10}$ e Mary Wollstonecraft se encaixava, portanto, como uma pensadora de cunho iluminista, embora se portasse crítica à aplicação das bases racionais apenas aos homens. E no seio das mudanças principais da época do esclarecimento, as Revoluções Francesa e a Industrial acabam se revestindo de caractere especial para o cotejo da obra da autora e de Rousseau. Isso porque todos os principais eventos erigidos pelo século XVIII e início do século XIX tiveram como delineamento a erupção desses dois movimentos. Assim, entre os acontecimentos mais elementares, menciona Burns (2005, p. 478) o espargimento e propalação do liberalismo burguês, o enfraquecimento e ruína das aristocracias fundiárias e o contínuo despertamento da consciência de classe pelos trabalhadores.

Saliente-se, ainda, que a constituição das Revoluções se dá no amparo oferecido pelas ideias científicas delineadas pelos "luminares" - autores como Copérnico, Galileu, Newton, Locke, Montesquieu e Rousseau... - que serviram de base epistêmica ao ideário das revoluções supracitadas, causando a evolução do iluminismo e a revolução sem precedentes na sociedade e no uso da técnica (MELLO; DONATO, 2011, p. 249).

Nessa arquitetura histórica, na Inglaterra de Mary, o capitalismo industrial que se desenvolveu significou também importante mola propulsora das transformações ocorridas na

\footnotetext{
${ }^{9}$ Edgar Morin (2005, p. 24) explicita a conexão entre os termos afirmando "Depois da explosão do Renascimento, o século das Luzes foi um momento capital na história do pensamento europeu. A grande dialógica aberta após a Renascença, ou seja, a relação, ao mesmo tempo, antagônica e complementar entre fé e dúvida, razão e religião, teve o seu ponto central em Pascal, homem de fé e de dúvida. Essa grande dialógica, no século do Iluminismo, foi marcada pela preponderância (talvez hegemonia) da razão. É certo que o Renascimento, acontecimento histórico que possibilitou a ressurreição da filosofia não mais como serva da religião, restabeleceu e retomou o tema da autonomia da razão oriunda dos gregos e permitiu, com Galileu, Descartes e Bacon, o desabrochar da ciência baseada em procedimentos empírico-racionais".

${ }^{10}$ Danilo Marcondes (2005, p. 139) afirma que para nós, atualmente, o conceito de modernidade se relaciona ao que é novo, bem como aos temas que rompem com a tradição, associando-se ao sentido de mudança com conteúdo positivo, divisando a mudança, a transformação e o progresso, embora os pensadores desse tempo não se autodenominassem "modernos".
} 
Europa do século XVIII. A Inglaterra industrializada se tornou o maior império colonial da época, sustentada pelo tráfico negreiro e pela exploração colonialista da África e América por meio da implantação do conhecido sistema do plantation. No ínterim desse sistema de economia, em apertada síntese de acontecimentos, os Estados Unidos declaram sua independência (1776) e a França vive, como alhures alocado, o mais definitivo e radical período da Revolução de 1789. A Inglaterra declara guerra à França e os ingleses são tidos por traidores. Inicia-se, também, forte movimento abolicionista nas terras britânicas (HOBSBAWM, 1996, p. 79).

Neste terreno, em breve considerações que mesclam a história e as ideias depositadas, está o momento de formação da autora como escritora da obra Reivindicação dos Direitos da Mulher. Daí a necessidade de contextualização histórica e de contraposição com o iluminismo “mainstream” de seu tempo, representado no capítulo a seguir por Rousseau.

\section{REIVINDICAÇÃO DOS DIREITOS DA MULHER: RESPOSTA AO ILUMINISMO PATRIARCAL}

Mary Wollstonecraft se mostra uma autora imersa no pensamento de seu tempo, reconhece o esclarecimento iluminista e questiona o porquê de a mulher não estar incluída nele. O iluminismo como pensamento filosófico se volta para a necessidade de emancipação do ser humano, de modo que é impossível versar sobre o tema sem sopesar o opúsculo de Kant de 1784, Resposta à Pergunta: O que é o Iluminismo?, no qual procura explicar as bases do movimento. Para o filósofo de Königsberg, o iluminismo representa a emancipação do homem de sua condição de menoridade, pela qual somente ele é responsável. Significa um apelo à autonomia do ser humano, que é desafiado a pensar por si mesmo, usando a razão como esteio de seus pensamentos e de sua ação (moral). $\mathrm{O}$ autor clama as pessoas a ousarem a pensar: sapere aude ${ }^{11}$ :

\footnotetext{
${ }^{11}$ Por volta de 20 a.C., Horácio, poeta e filósofo da Antiga Roma, em Epistularum liber primus, na carta 2, versejou "dimidium factti qui coepit habet: sapere aude", que, em tradução livre, significa, "aquele que começou está na metade da obra: ouse saber”. Séculos antes da Idade das Luzes, o poeta versara, numa amálgama de inquietações
} 
Esclarecimento (Aufklärung) significa a saída do homem de sua minoridade, pela qual ele próprio é responsável. A minoridade é a incapacidade de se servir de seu próprio entendimento sem a tutela de um outro. É a si próprio que se deve atribuir essa minoridade, uma vez que ela não resulta da falta de entendimento sem a tutela de outro. Sapere aude! Tenha coragem de te servir de teu próprio entendimento, tal é, portanto, a divisa do esclarecimento. (KANT, 2008, p. 1).

A revolução por trás do "sapere aude" sintetiza, em poucas palavras, o levante gêmeo das transformações teóricas e políticas que caudificaram o século XVIII. Proclama a emancipação do pensamento por meio da razão, anunciando a capacidade humana de buscar o conhecimento como meio de atingir sua "maioridade" enquanto pessoa. Tal preceito inspirou toda a geração de luminares que militavam pela defesa da vida humana digna e pode ser visto também como um desafio de Wollstonecraft às mulheres de seu tempo:

\begin{abstract}
Os homens têm várias ocupações e objetivos que prendem sua atenção e dão caráter à mente aberta; mas as mulheres, confinadas a uma única ocupação, com seus pensamentos constantemente dirigidos para a mais insignificante parte de si mesmas, raramente estendem suas reflexões além do triunfo do momento. Porém, caso seu entendimento fosse emancipado da escravidão a que foram submetidas pelo orgulho e pela sensualidade do homem e por seu desejo míope de domínio, semelhante ao dos tiranos, provavelmente leríamos com surpresa a respeito da fragilidade feminina (WOLLSTONECRAFT, 2016, p. 66).
\end{abstract}

O legado iluminista, portanto, ao mesmo passo em que apregoava o caráter perfectível e perscrutável da razão e a necessidade elementar da instrução pública para homens - isto é, a emancipação humana por meio do uso da razão e a imprescindibilidade desta no viver social do Estado - apoiava, em contrapartida, discurso de subordinação da mulher ao homem, delegando-lhe um estado de eterna "minoridade". Era-lhe solapado o acesso à escolarização e aos "ambientes de conhecimento", sendo que sua educação haveria de restringir-se à responsabilidade familiar.

Nesse cenário, Wollstonecraft tece críticas diversas em face do tratamento discriminatório da mulher, tal como na já citada carta ao bispo e político Charles-Maurice de Talleyrand-Périgord (1754-1838) ${ }^{12}$, na qual anuncia o caráter incongruente e incondensado de

poético-ontológicas, sobre a capacidade humana de emancipar-se através do conhecimento. Utilizando-se da linguagem lírica, remete-nos a questionamentos de ordem filosófica nos quais se devaneia sobre a necessidade do "conhecer" enquanto força humana incontornável, que subsiste a determinantes de tempo-espaço por ser ferramental ínsito ao humano. A razão, isto é, a capacidade humana de tracejar caminhos epistêmicos para apropriar-se da vida, seria, pois, condição para a própria emancipação do ser, para o processo de humanização e pessoalização do indivíduo. "Sapere aude" acabou por tornar-se, séculos mais tarde, o lema epistemológico do Iluminismo. Immanuel Kant, contemporâneo de Mary Wollstonecraft, quando questionado sobre o que seria a idade das luzes, faz uso da expressão.

${ }^{12}$ Charles-Maurice de Talleyrand-Périgord, durante a Revolução Francesa redigiu documento titulado "Rapport sur I'intruction publique" (1791), exposto e debatido na Assembleia Constituinte da França. O escrito ratificava 
certas verdades iluministas que, excetuando as mulheres dos direitos universais apregoados em seu esteio, condenavam-nas ao estado perene de subordinação ao masculino, sentenciando-as a nunca amadurecer. No contrafluxo, rebate o Bispo ao dizer que "[...] o tema da emancipação pela Razão foi superficialmente tratado, contentando-se em considerá-lo como sempre foi feito, quando os direitos do homem não aludem aos direitos da mulher por serem estes rebaixados como quiméricos e inferiores" (WOLLSTONECRAFT, 2016, p. 19).

O que se percebe é que há, na locução da autora, denúncia de verdadeira aniquilação da participação feminina no projeto iluminista, feita através da hierarquia familiar (homem e mulher) e permitindo, ainda, a metonímia de uma classe dominante que não alarga, ou mesmo compreende, o sentido dos valores universais que se apregoavam:

Trago o afeto por todo o gênero humano. É o que faz minha pena escrever rapidamente: apoiar o que acredito ser a causa da Virtude; e a mesma razão me leva a desejar ver a mulher em uma posição a partir da qual avance, em vez de ser refreada, sem qualquer chance de acesso ao progresso dos princípios que dão substância à moralidade e à razão". (WOLLSTONECRAFT, 2016, p. 20).

No capítulo em que tece argumentos sobre o caráter sexual que subverteu os juízos de valor em relação à mulher, expõe que "a Razão é, consequentemente, o simples poder do aperfeiçoamento, o poder de discernir a verdade. Nesse sentido, cada indivíduo constitui um mundo em si mesmo. Evidencia-se mais em uns do que em outros, mas a natureza da Razão deve ser a mesma em todos" (WOLLSTONECRAFT, 2016, p. 41). Afirmando que a razão iguala as pessoas, demostra que a sociedade de sua época se efetiva a partir de uma lógica de diferenciação sexual na qual a plena agência moral dos indivíduos está atrelada ao gênero, e assim também a independência da atuação política e do exercício da cidadania. Propõe, então, o alargamento sensível e intelectual dessa realidade iluminista afirmando a natureza essencial da dignidade humana como algo comum a todos.

Ora, se é verdade que as equalizações sociais no âmbito do Esclarecimento se principiam pelo despertar da razão e se desenvolvem sob a luz da efetivação do princípio da dignidade e

o processo de aperfeiçoamento moral-humano por que passava o homem (no sentido masculino e não como sinônimo de humanidade) através da Razão. Afirmava, outrossim, a necessidade de realização de amplo acesso à instrução para homens. A última página do documento versa sobre a educação e condição da mulher - atreladas à responsabilidade familiar. 
da igualdade humana, Wollstonecraft delineia e institui em sua obra o ofício desse cuidado e, num tom menos contundente, flagra a palpável incoerência das injustiças de sua época.

A polarização “masculino/feminino" esboçada é resultado de pensamento alvitrado por desiguais, tão debatido por filósofos e cientistas das variadas áreas do saber. Vislumbra-se essa polarização no correr de alguns momentos da história e da tradição filosófica iluminista, em nítida transposição da sua esfera lógica, ética, ontológica e epistêmica - campos preferencialmente habitados pelo pensamento racional-categorial - para fincar suas vigas de sustentação unicamente em conceitos biológicos. Com efeito, é absolutamente inferível que a divisão dos sexos (masculino e feminino) radica o caractere biológico da diferenciação dos seres vivos. Muitos pensadores do iluminismo, porém, olvidaram que este seria um dimorfismo meramente físico, carregando essa distinção, de modo sexista, para o cânon, para a norma e, por conseguinte, implicando-a no ethos social.

O que se pauta nesse discurso é que diferentes estruturas de pensamento racional instauram a predileção de um polo dominante, capaz de gerir o polo dócil e submisso que o $\operatorname{subjaz}^{13}$ :

Como se supõe da ética cristã que Eva era, literalmente, uma das costelas de Adão, tal dedução deve ser admitida apenas como prova de que o homem, desde a mais remota Antiguidade, achou-a conveniente para exercer sua força, a fim de subjugar sua companheira, e utilizou sua invenção para mostrar que a mulher deveria ter seu pescoço sob jugo, porque toda a criação foi feita apenas para a sua conveniência e prazer. (WOLLSTONECRAFT, 2016, p. 47).

Aventa-se, na fala da autora a composição de um modelo comum: o contínuo sopesamento do status moral da mulher em face de um código, ou modelo, masculino. É o

\footnotetext{
13 Buscando na tradição filosófica, por ilustração, já Aristóteles (2014, p. 116). - primeiro "antropólogo" a estabelecer a ideia da dicotomia dos sexos em dois polos: negativo (mulher) e positivo (homem) - admite a existência de diferenciação biológica que, em certos momentos de análise e articulação, denota a característica natural da inferioridade feminina. Tal colocação reverbera não apenas em seus escritos de análise naturalbiológica, mas sobretudo quando trata da teleologia que analisa a natureza comoforma e essência. Nessas noções, para o estagirita, a natureza demostra a aptidão masculina para desempenhar um papel hegemônico na casa e na polis, ratificado, outrossim, pela assunção de qualidades e virtudes que (re)legitimam seu domínio nesses ambientes. Num outro passo histórico, a ética cristã medieval retoma as ideias aristotélicas e estabelece, num horizonte racional epistêmico, que as qualidades positivas humanas estavam necessariamente incutidas no homem e as negativas se alocavam na mulher, em razão - óbvia - da fisionomia, da biologia, do sexo. Isto é, para Igreja, a mulher "possui os vícios" por causa do corpo e da alma. Nunca é a imagem e semelhança do homem, de Deus. Segundo Michelet, (1991, p. 143), a composição da imagem feminina neste período histórico parte da pregação da "Eva pecadora" e tem seu ápice no Renascimento, momento em que torna-se feiticeira - figuração que irá perdurar até meados do século XVII e a imagem de "Maria redentora", na dística propalação da beleza ímpia e da beleza sagrada.
} 
homem que define o verbum mentis do que é o humano, do que é a pessoa, excetuando as mulheres dessa composição. Assim, "o que revela a História senão as marcas da inferioridade e o modo como poucas mulheres se emanciparam do julgo exasperante do homem soberano? WOLLSTONECRAFT, 2016, p. 57).

Nas condições objetivas explanadas pela autora observa-se o lançar-de-mão de substantivos que demandam análise por sua contiguidade: natureza/biológico, masculino/feminino. Na aparente imparcialidade das elocuções, resultantes da observação dos fenômenos da vida, grão-a-grão se sedimentam valorações que atestam um elemento forte e um elemento fraco; um polo legitimado a dominar e um polo resguardado a obedecer; algo que estabelece, representa e diz a norma, e algo que personifica mais uma esfera de tutela.

Num nível imediato, a estrutura hierárquica passa do sedimento para a solidificação geracional. Paulatinamente, um dos polos categoriais é posto como arquétipo a ser seguido e outro, seu par, é secundarizado. A pergunta “o que é o homem”, desde a antiguidade ressoando na filosofia, atravessa a diferenciação, no Iluminismo, até encontrar sua unidade - a pessoa. A expressão "homem", porém, utilizada desde sempre para significar a totalidade das pessoas, passou ilesa e não desconfortou grande parte das sociedades. De igual modo, também grande parcela dos filósofos não lhe denotou preocupações até o século $\mathrm{XX}$, nem mesmo os grandes mentores do século Iluminado. A homogeneidade da terminologia é simbólica e sintomática. No que concerne à filosofia, esboça o significante precípuo de um modelo que se impõe, um espectro masculino pensado e escrito por homens que não coloca a mulher em mesmo patamar.

\subsection{A mulher educada: vindicação do Direito da mulher à escolarização formal}

Nesse caminho, seguindo o recorte metodológico escolhido, traz-se à balança "Emílio ou da Educação", obra pedagógica do "cidadão de Genebra" ${ }^{14}$ Jean-Jacques Rousseau, escrita em 1762, que confina, em suas laudas, temas de cunho filosófico e político relacionados ao indivíduo-homem e sua subjacente sociedade. O tema central será, por ora, a educação ${ }^{15}$. Para

\footnotetext{
${ }^{14}$ Como gosta de se referir Mary Wollstonecraft a Rousseau, nascido em Genebra.

${ }^{15}$ Assunto que é considerado sensível e essencial por Wollstonecraft, que sempre está indagando a sociedade sobre a necessidade de boa educação aberta a todos, além de focar, também na Razão como algo universal e na liberdade como elemento ínsito de todo ser humano (revelando sua situação histórico-iluminista), como se percebe, por
} 
o contratualista, o homem é bom por natureza e a sociedade é o elemento corruptível que o subverte $^{16}$. Rousseau se utiliza da figura de "Emílio" para construir, em cinco capítulos, o "perfill" do homem em um sistema de educação que lhe possibilite emancipar-se (sapere aude!) por meio do uso da razão e, por conseguinte, desviar-se das nuances corruptíveis do meio social, tornando-se, por fim, um "cidadão ideal".

Em seu quinto e último capítulo, titulado "Sofia ou a Mulher”, Rousseau faz a descrição do modelo de "mulher ideal", educada para ser esposa de Emílio. Suas palavras são esclarecedoras no que trata de se compreender - em seu tempo e, quiçá, também na época atual - o uso do argumento biológico (o gênero feminino) para pautar a agência moral de uma pessoa, caracterizando a desigualdade com que era tratada mulher no que concerne à capacidade moral de gênero. Para o filósofo,

Sofia deve ser mulher como Emílio é homem. (...) Em tudo que diz respeito ao sexo, a mulher e o homem têm em tudo relações e em tudo diferenças: a dificuldade de compará-los vem da de determinar, na constituição deles, o que é do sexo e o que não é. Tais relações e tais diferenças devem influir no moral. Na união dos sexos cada qual concorre igualmente para o objetivo comum, mas não da mesma maneira" (grifo nosso) (ROUSSEAU, 1999, p. 306).

Em sua argumentação, faz nítida alocação de funções: Sofia “deve ser mulher”, assim como Emílio "é homem”. Os gêneros seriam, então, diferentes não apenas no aspecto físico, mas, sobretudo, no filosófico, no que atine à autonomia e, consequentemente, num jaez nitidamente iluminista, na questão da liberdade. Nesse sentido, o discurso de Rousseau conduz à conclusão de que a diferenciação entre os gêneros adviria das condicionantes biológicas de cada ser (especificamente, do gênero), e influenciaria na agência moral e social dos indivíduos

exemplo, na seguinte passagem: "Na luta pelos direitos da mulher, meu principal argumento baseia-se neste simples princípio: se a mulher não for preparada pela educação para se tornar a companheira do homem, ela interromperá o progresso do conhecimento e da virtude; pois a verdade deve ser comum a todos ou será ineficaz no que diz respeito a sua influência na conduta geral. Como se pode esperar de uma mulher que ela colabore, se nem ao menos sabe por que deve ser virtuosa? A não ser que a liberdade fortaleça sua razão, até que ela compreenda seu dever e veja de que maneira este está associado ao seu bem real"' (2016, p. 20).

${ }^{16}$ Em pelo menos dois discursos distintos fica muito claro esse posicionamento em Rousseau, no Do Contrato Social afirma "O homem nasceu livre, e por toda a parte geme agrilhardo;" (2006, p. 23), nas notas do Discurso Sobre a Origem da Desigualdade, afirma, corroborando sua posição favorável à inocência do homem précivilizado: "Os homens são maus: uma triste e contínua experiência dispensa a prova; no entanto, creio ter demonstrado que o homem é naturalmente bom. O que pôde então depravá-lo até esse ponto, senão as mudanças sobrevindas em sua constituição, os progressos que ele fez e os conhecimentos que adquiriu? Por mais que se queira admirar a sociedade humana, não é menos verdade que ela leva necessariamente os homens a se odiarem entre si à medida que seus interesses se cruzam, a se prestarem aparentemente serviços mútuos e, em realidade, a praticarem todos os males imagináveis. O que se pode pensar de um comércio no qual a razão de cada indivíduo lhe dita regras de conduta contrárias àquelas que a razão pública prega ao conjunto da sociedade e no qual cada um obtém sua vantagem da infelicidade de outrem?" (2013, p. 1775) 
sociais, impondo-lhes papeis "pré-estabelecidos" pela natureza. Desse modo, a educação do homem - voltada para seu aperfeiçoamento moral e, por fim último, para o bom funcionamento da engrenagem social - deve ser díspar da educação oferecida à mulher que, nessa assunção de atribuições, é personagem secundária, "passiva", responsável tão-somente por tornar "mais agradável" o tortuoso caminho a ser percorrido pelo homem.

O iluminista prossegue afirmando que

Dessa diversidade entre Sofia e Emílio nasce a primeira diferença assinalável entre as relações morais de um e de outro. Um deve ser ativo e forte (homem), o outro passivo e fraco (mulher): é necessário que um queira e possa, basta que o outro resista pouco. Estabelecido este princípio, segue-se que a mulher é feita especialmente para agradar ao homem" (ROUSSEAU, 1999, p. 307).

Não obstante, arremata:

Se o homem deve agradar-lhe por sua vez, é necessidade menos direta: seu mérito está na sua força; agrada, já, pela simples razão de ser forte. Não se trata da lei do amor, concordo; mas é a da natureza, anterior ao próprio amor (ROUSSEAU, 1999, p. 307). (grifo nosso).

Note-se, nessa senda, que a individualidade-pessoalidade moral da mulher se revela sequestrada e esterilizada por uma injunção de ideias que lhe nega acesso à educação e inclusão na vida pública, atribuindo valoração naturalístico-determinística a essa situação. "As mulheres têm de ser consideradas como seres morais" (WOLLSTONECRAFT, 2016, p. 46), o argumento ressoa no enfrentamento de premissas moralistas, sexistas e, na visão contemporânea, conservadoras. Wollstonecraft cogita a inferioridade intelectual feminina de seu tempo como algo que se justifica exclusivamente pelos "pré-juízos" de uma ordem social que limita e domina a existência da mulher, ao passo em que naturaliza a condição de submissão, de inferioridade e de sujeição. Uma vez mais há visível antagonismo entre os valores iluministas, hasteados pela Revolução, e sua concretude excludente - às mulheres - que, ao invés de assomar e emancipar a pessoa, a subtrai.

Wollstonecraft alerta, pois, que as mulheres eram educadas no seio familiar para o aprendizado dos assuntos do lar, sempre dependentes da autoridade masculina. Eram filhas educadas para se tornarem esposas ${ }^{17}$. O padrão cultural das classes superiores na Europa do

${ }^{1717}$ Como o faz, de modo um pouco sarcástico: "Deixem-me argumentar com os apoiadores dessa opinião que têm algum conhecimento da natureza humana se eles imaginam que o casamento possa erradicar um hábito de vida. A mulher que tem sido ensinada apenas a agradar logo descobrirá que seus encantos são raios de sol oblíquos e que 
final do século XVIII, somado às regras patriarcais vigentes e enraizadas, circunscreviam a educação da mulher ao adestramento para o marido e para o matrimônio. A mulher era a responsável pela solidez do ambiente familiar, educada para consolidar um lar acolhedor, com filhos polidos, dedicada ao marido e desobrigada de qualquer tarefa produtiva. Seu mundo limitava-se à sua casa, devendo sempre guiar-se pela retidão e probidade $\operatorname{caseiras}^{18}$.

Rousseau (2006, p. 24) explica a família como a primeira sociedade existente, e a única natural, seio de criação da primeira diferenciação na forma de viver de ambos os sexos: “As mulheres passaram a ser mais sedentárias e se acostumaram a cuidar da cabana e dos filhos, enquanto o homem ia buscar a subsistência comum" (2013, p. 1148). Esse seria, portanto, o "papel social" da mulher. De outro modo, completamente rechaçada seria aquela destoasse desse modelo. Fazendo um breve recorte até tempos mais próximos, o mesmo fim teria aquela que fosse "Capitu", personagem machadiana (2018, passim) criada no Brasil, já no póstero século XIX: adúltera, dissimulada e sensual, responsável pela corrupção e loucura do homem, seu marido, por não corresponder às expectativas de esposa ideal; ou que fosse Joana, heroína criada por Clarice Lispector (2019, passim) em 1942 que, por não se dispor à submissão a um casamento sem mútua vontade, cujo destino natural da mulher seria sua coadjuvação ingênita e perpétua e, do homem, a disposição de todas as forças da mulher para sua própria fogueira, é preterida ao abandono social como peça que não funciona... Ou, voltando ao Século das Luzes, que fosse como Maria, personagem da própria Wollstonecraft em "Maria: ou, os erros da Mulher"19 (1798), obra inacabada em que romantiza o destino das mulheres que ousassem discordar de seus senhores. "Não agem vocês de maneira injusta quando forçam todas as

\footnotetext{
estes não podem ter muito efeito sobre o coração de seu marido quando "são vistos todos os dias, quando o verão passou e está findo" (2016, p. 48).

${ }^{18}$ A autora se mostra perplexa com o tipo de educação, passiva e inerte, da mulher que, impedida de atingir sua própria independência não poderia, em tese, ser boa gerente sequer da família: " $E$ as mulheres que, desde cedo, incorporaram noções de obediência passiva possuem caráter suficiente para gerenciar uma família e educar os filhos?" (WOLLSTONECRAFT, 2016, p. 56).

${ }^{19}$ O Romance póstumo, publicado em 1798 por seu marido, William Godwin, é reportado como sendo a versão literária da "Reivindicação dos Direitos da Mulher", representando, de maneira brava e inovadora para o seu tempo, a história de Maria, uma mulher encarcerada por seu marido inescrupuloso num hospício. A obra é perpassada de passagens verdadeiramente instigantes e inspiradoras para o seu tempo, não apenas acerca da estigmatização do feminino, mas também sobre os problemas sociais que infligiam a sociedade e o contraste que tudo isso provocava do alheamento à realidade dos filósofos iluministas: "Como os escritores, que se dizem amantes da liberdade e do progresso moral, podem afirmar que a pobreza não é um mal, é algo que não posso explicar". Tradução livre de: "How writers, professing to be friends to freedom, and the improvement of morals, can assert that poverty is no evil, I cannot imagine" (WOLLSTONECRAFT, 2016, pp. 121-122).
} 
mulheres, aos negar-lhes os direitos civis e políticos, a permanecer confinadas na família, reduzidas ao escuro?" (WOLLSTONECRAFT, 2016, p.19).

Cum grano salis, a educação da mulher para ser "bela, recatada e do lar" de Rousseau se mostra diametralmente inversa à educação emancipatória defendida por Mary Wollstonecraft, cuja ênfase centra-se na reinvindicação de que possa exercitar o seu entendimento e exercer a Razão, no que é igual ao homem ${ }^{20}$. A filósofa assevera, pois, que “[...] contudo, Rousseau e a maioria dos escritores masculinos que seguiram seus passos, calorosamente inculcaram que toda a tendência da educação feminina deve ser direcionada para um ponto: torná-las agradáveis" (WOLLSTONECRAFT, 2015, p. 52; 54). Nesse cenário, declara que, em sua sociedade, não bastassem as limitações institucionais que balizavam a presença feminina em ambientes de escolarização e ensino formais, o cultivo pela mulher de algum Entendimento subordinava-se à apresentação de dotes físicos - graça, docilidade e beleza. Questiona, todavia: como oferecer potência à fala e razão feminina se, já na mais tenra idade, sua faculdade intelectiva é orientada de modo a tornar-se e a conformar-se como a companheira ideal do protagonista social determinante, o Homem, desenvolvendo maneiras convencionalmente pré-estabelecidas? Se permanece, a mulher, inexoravelmente destinada a tornar-se como a Sofia de Rousseau? "Por não contarem com estudos científicos sérios, a capacidade das mulheres não é estimulada pela emulação, sua sagacidade natural volta-se cedo demais para dar vida a boas maneiras" (WOLLSTONECRAFT, 2016, p. 44).

De mais a mais, é importante salientar que Wollstonecraft pode ser considerada a primeira pensadora a distinguir sexo e gênero, o que corrobora sua fama protofeminista. Apesar de não utilizar tais nomenclaturas, acabara pré-moldando terreno teórico que hoje distingue o biológico e o cultural e que seria, contemporaneamente, o espeque dessa diferenciação. Segundo a autora, ainda em rebate ao filósofo contratualista,

Quanto às observações de Rousseau de que a mulheres naturalmente têm, provenientes de seus nascimentos, independente da educação, um carinho pelas bonecas, vestimentas e conversas, meninas e meninos, resumidamente, brincariam

\footnotetext{
${ }^{20}$ É interessante apontar que a autora se mostra diretamente contra às ideias de Rousseau, no que tange à segregação educacional das pessoas com base no sexo: "Mas continuo insistindo que não só a virtude, como também o conhecimento dos dois sexos deveria ser o mesmo em natureza, se não em grau, e que as mulheres, consideradas criaturas não apenas morais, como também racionais, deveriam se esforçar para adquirir virtudes humanas (ou perfeições) mediante os mesmos meios que os homens, em vez de serem educadas como uma espécie de criatura imaginária pela metade - uma das extravagantes quimeras de Rousseau" (WOLLSTONECRAFT, 2016, p. 62).
} 
inofensivamente juntos, se a distinção do sexo não fosse inculcada muito antes da natureza fazer qualquer diferenciação. (WOLLSTONECRAFT, 2015, p. 69-71).

A autora constatou, nesse cenário, as assimetrias e desequilíbrios a que eram submetidas suas contemporâneas, notando a complexa teia social que as privava e as reprimia de desenvolver suas aptidões e potencialidades, retirando-lhes qualquer autonomia e impedindolhes de atingir sua "maioridade". Dessa forma, seu feminismo iluminista recai sobremaneira no estudo ontológico-filosófico da mulher e nas implicações sociais-jurídicas acerca dos efeitos do impedimento - cultural e institucional - de oportunizar ao feminino o acesso à educação. No núcleo de tais elucubrações, alude que as mulheres,

\footnotetext{
Ligadas ao homem enquanto filhas, esposas e mães, têm seu caráter moral estimado pela maneira como desempenham esses simples deveres; mas o fim, o grande fim de seus esforços, deveria ser desenvolver suas próprias faculdades e obter a dignidade da virtude consciente" (WOLLSTONECRAFT, 2016, p. 47).
}

Sob nova chave, não há de se olvidar que tal modelo de educação circunscrita buscava, também, a perpetuação do processo de "docilidade dos corpos" femininos, fazendo com que se mencione, inevitavelmente, Foucault, para quem "é dócil um corpo que pode ser submetido, que pode ser utilizado, que pode ser transformado e aperfeiçoado" (2009b, p. 164). Nesse conúbio ideológico da Era Moderna, as formas de controle, dominação e repressão do corpo da mulher foram progressivamente aperfeiçoadas, mormente dentro do modelo de educação a que eram submetidas. Referido domínio, suplanto e domesticação do corpo da mulher, ocorriam em sede de imposição social, sob amparo da própria tradição filosófica que fornecia argumentos de naturalização dessa servidão. Note-se a esquálida altura das relatadas contradições: se, por um lado, várias formulações de pensamento iluminista radicavam que a mulher era, naturalmente, criada para a passividade e submissão, por outro, expunham a necessidade de aplicação de projeto pedagógico para a adestração e domesticação do feminino.

Esse modelo de educação destinado à mulher faz tabula rasa de tudo aquilo que conforma e constitui seu universo, mitigando sua identidade feminina em detrimento de um espectro masculino. Nesse cenário, a mulher não é cidadã plena. Sua personalidade é tutelada sob o estigma de uma inferioridade intelectiva. É-lhe relegado o terreno das emoções e o banimento do campo da razão. Por esse ângulo, Wollstonecraft inscreve sua autoria sobretudo na defesa do acesso pelas mulheres à educação formal e na luta pela universalidade de direitos. Se esforça em comprovar que "a razão exige e clama em voz alta por justiça para metade da raça humana" (WOLLSTONECRAFT, 2016, p. 30) e busca lançar um novel olhar 
interpretativo sobre os conceitos de igualdade e justiça de seu tempo entre os sexos: homens e mulheres deviam desfrutar do mesmo tratamento na sociedade. Nesse engendrar, lança um desafio:

\begin{abstract}
As mulheres têm ocupado patamar que as impõem um lugar quase abaixo das criaturas racionais. Deixemos espaço para que suas faculdades se desenvolvam e suas virtudes ganhem forças e, então, decidiremos qual deve ser a posição do sexo feminino, por inteiro, na escala intelectual. (WOLLSTONECRAFT, 2016, p. 56).
\end{abstract}

Em suma, há de ser dito que Wollstonecraft vivera numa época em que a mulher tinha seus direitos abjurados pela ordem institucional, em que era completamente excluída da vida pública e do acesso à educação, em que era supressa de ambientes de conhecimento, tais como universidades, e banida de quaisquer possibilidades de carreiras profissionais. Nascia com destino inequivocamente arquitetado: o casamento, que sucederia a tutela legal do pai para a do marido, proibindo a gestão pessoal de seus bens e, tampouco, o trabalho fora do ambiente do lar. Numas das passagens mais pungentes de "Maria: Ou, Os Erros da Mulher" a protagonista do romance descreve à sua filha, ainda não-nascida, em diário, o triste fado de sua irmã, recentemente morta, muito bem-educada e com inteligência acima do comum, mas que não podia exercer nenhuma atividade laboral, senão aquelas que a sociedade de seu tempo lhe permitia (WOLLSTONECRAFT, 2016, p. 146):

Eu velei seu leito de enferma por alguns meses, então fechei seus olhos, gentil espírito!, para sempre. Era bela, com modos muito envolventes; no entanto, nunca teve a oportunidade de se casar, exceto com um homem muito velho. Possuía habilidades suficientes para brilhar em qualquer profissão, se houvesse profissões para mulheres, embora tenha retrocedido ante a possibilidade de modista ou costureira por tomá-las por degradantes a uma dama. Não nominaria esse sentimento como um falso orgulho a ninguém, a não ser você, minha filha, a quem ainda carinhosamente espero (sim; me entregarei à esperança, por um momento) que possua aquela energia de caráter que confere dignidade a qualquer posição; e com esse espírito claro e firme que permitirá que você escolha uma situação para si mesma, ou se submeta à classe mais baixa, se esse for o único meio no qual você poderá ser a senhora de suas próprias ações $^{21}$.

É evidente que sua voz, no horizonte da Era da Razão, proclama e defende, em um ambiente social extremamente hostil, a Reinvindicação dos Direitos da Mulher. E o faz usando

\footnotetext{
${ }^{21}$ Tradução livre dos autores de: "I watched her sick bed for some months, and then closed her eyes, gentle spirit! for ever. She was pretty, with very engaging manners; yet had never an opportunity to marry, excepting to a very old man. She had abilities sufficient to have shone in any profession, had there been any professions for women, though she shrunk at the name of milliner or mantua-maker as degrading to a gentlewoman. I would not term this feeling false pride to any one but you, my child, whom I fondly hope to see (yes; I will indulge the hope for a moment!) possessed of that energy of character which gives dignity to any station; and with that clear, firm spirit that will enable you to choose a situation for yourself, or submit to be classed in the lowest, if it be the only one in which you can be the mistress of your own actions".
} 
primeiramente mudança na educação da mulher. Isso tudo com o sonho de ver acontecer a revolução "nos modos das mulheres", "indo da injustiça para a justiça”.

\subsection{A pessoalidade da mulher: vindicação da personalidade jurídica da mulher na obra}

"Pessoa"; pletórica palavra cuja raiz etimológica mais remota descansa no grego "prósopon” (significando aspecto). "Pessoa"; enigma que remonta aquilo que os latinos, no seu passo semiótico, denominaram "persona": as máscaras utilizadas pelos atores nas cenas teatrais e os personagens inflados de vida nas representações que se criavam (MICHAELIS, 2019). "Pessoa"; palavra que o Direito tanto preza, fazendo exaltação de sua proteção em suas extensões constitucionais, nas quais acrescenta-lhe o adjetivo da dignidade. Tudo isso surge à mente quando, de imediato, se tenta elucubrar sobre o que é ser pessoa: mas o que seria, em tese conceitual — num abrigo social e jurídico — a pessoa?

Apartando o conceito de sua sinonímia mais próxima, ou seja, "ser humano", explicase (LIMA JR, 2017, p. 28) que, numa análise que avalize a significância social e jurídica em sentido contemporâneo, "ser humano" e "pessoa" são conceitos complexos e distos que, dentro da patente necessidade de sistematização, pertencem a ramos de estudo diferentes. Por "ser humano" pode-se designar aquele que é membro da espécie humana. O "indivíduo", por extensão, seria a unidade da espécie que, portanto, ainda faz parte das definições da ciência biológica. Mas "a pessoa", contudo, tal como parece no evoluir da sociedade, parece ir além desse biologismo, compartimentando apenas essa suposição material/biológica. O que se concebe no ser humano, ao dizê-lo e compô-lo pessoa, é de injunção imaterial, incorpóreo: é moral.

Voltando-se a essa inferência de pessoa, e regressando ao delineamento iluminista, alude Kant que "a pessoa é esse sujeito cujas ações são suscetíveis de imputação. A imputação, no sentido moral, é o juízo pelo qual se olha para alguém como autor de uma ação" (2005 p. 457). Quem pensa pessoa, sendo assim, consubstancia sujeito e liberdade (moral). À medida que é "ser humano" (face natural), o homem é o composto das características organogênicas da espécie. Ao passo que é "ser de razão", torna-se apto a determinações de ordem ética, não mais 
agindo conforme injunções das leis naturais, mas em obediência aos imperativos da sua vontade autônoma.

Portanto, à pessoa vincula-se a agência moral e jurídica. Na seara do Direito Justo, pessoa é sujeito de direitos, quem detém personalidade jurídica e dignidade ínsita. Em sociedade de iguais, a mulher deve ser valorada de acordo com tais preceitos, "tem uma vida; é um ser humano; e, sobretudo, tem importância moral e jurídica: é uma pessoa" (LIMA JR, 2019, p. 79).

Se por pessoa tem-se o ser autônomo, consciente, responsável por seus atos; e se tem, de igual modo, a noção precípua da constituição de direitos e da importância-significação social (moral e jurídica) do indivíduo; a "Reinvindicação Dos Direitos da Mulher" é um manifesto inconteste pela legitimação da pessoalidade e, por consequência, da personalidade jurídica da mulher enquanto "sujeita" de direitos e deveres, enquanto detentora de dignidade, enquanto pessoa, o que jamais poderia lhe ser outorgado diante das situações excludentes reportadas por Wollstonecraft:

\begin{abstract}
A fim de explicar e desculpar a tirania do homem, diversos argumentos engenhosos têm sido apresentados para provar que dois sexos, na busca da virtude e razão, devem ter em vista caminhos diferentes - ou, para falar francamente, não se admite que as mulheres tenham suficiente força mental para obter aquilo que realmente merece $o$ nome de virtude ou racionalidade. No entanto, se reconhecemos que elas têm alma, poderíamos pensar que há apenas um caminho possível conduzindo a humanidade à virtude e à justiça. (WOLLSTONECRAFT, 2016, p. 40).
\end{abstract}

$\mathrm{Na}$ força do fragmento, Wollstonecraft atenta para o fato de que, com a ressalva atinente às diferenciações próprias do sexo, outras dessemelhanças que porventura surjam entre homens e mulheres advêm tão-somente da construção social e são refutáveis pelo próprio emprego da razão. A "alma", mencionada como argumento igualitário pela autora, refere-se ao elemento que claramente denota a "personificação" da mulher, sua pessoalidade em paridade ao homem, aproximando-a muito de argumentos mais contemporâneos. A “alma” (dignidade) comum à pessoa, sem distinção de gênero, aloca-se como principal fundamento de sua petição pública. Para Ferreira (2009, p. 23), a autora ensaiava o primeiro andamento do chamado "feminismo liberal" (também conhecido como igualitário ou humanitário), cujo principal esteio de luta é a busca pela igualdade. Para além disso, porém, iniciava uma ventania permanente no cânon cultural patriarcal da época, elevando a ética e filosofia não apenas para a perspectiva feminina, mas para a voz feminina. Repisa-se: 
Se admitirmos que as mulheres detenham as virtudes humanas e, pelo exercício do entendimento, podem chegar à estabilidade de caráter que é a base mais sólida das nossas esperanças, a elas deve ser permitido voltar-se para a lua, e não serem forçadas a guiar o próprio curso pelo cintilar de um mero satélite. (WOLLSTONECRAFT, 2016, p. 41).

Saliente-se que até que se elevasse o princípio da igualdade à hermenêutica objetiva das constituições e legislações, farfalharam-se séculos e muitas outras personagens. Basta tomarmos como exemplo o ordenamento brasileiro. $\mathrm{O}$ voto feminino só passou a ser aceito com o Decreto n. ${ }^{\circ}$ 21.076, de 24 de fevereiro de 1932 (Código Eleitoral Brasileiro); de acordo com Beltrão e Alves (2009, p. 128), também apenas no final do século XIX deu-se início o acesso ao ensino superior pela mulher no Brasil; o instituto do pátrio poder, que circunscrevia a personalidade jurídica da mulher à tutela masculina, só deixou o sistema jurídico tupiniquim com o advento do "poder familiar", promulgado pela Constituição Federal de 1988 e literalmente expresso pelo novel código civil de 2002.

Em contraposição a Rousseau, no que tange à pessoalidade, observa-se uma distinção, talvez mais bem caracterizada como um esquecimento, da mulher ao longo do processo de independência do ser humano de suas condicionantes instintivas para, gradativamente, se emancipar, constituir família e sociedade e, portanto, se tornar um cidadão. No "Do Contrato Social", de fato, Rousseau sequer aventa a mulher ao afirmar que

\footnotetext{
"Imediatamente, em lugar da pessoa particular de cada contratante, esse ato de associação produz um corpo moral e coletivo [...] A respeito dos associados, tomam coletivamente o nome de Povo, e chamam-se em particular Cidadãos, como participantes da autoridade soberana [...]" (2006, p. 32).
}

Embora o autor use a palavra "pessoa", conforme se viu no capítulo anterior, a pessoalidade da mulher parece ser distinta da do homem, sua participação no Estado é nenhuma e seu governo é o doméstico. Em outras palavras, os direitos de participação política moderno lhe são supressos, algo que diminui sua consideração como pessoa, prejudicando-a na participação efetiva do projeto iluminista. Em vários trechos o autor genebrino coloca a mulher em posição de subalternidade pessoal ao homem, expondo que a regência daquela sobre este se faz através do apelo concupiscente, como se observa, indiretamente, na seguinte passagem de "Discurso sobre a origem e os fundamentos da desigualdade entre os homens":

Poderia eu esquecer aquela preciosa metade da república que faz a felicidade da outra, cuja doçura e cuja sabedoria mantêm a paz e os bons costumes? Amáveis e virtuosas cidadãs, o destino de vosso sexo será sempre governar o nosso. Excelente quando o vosso casto poder, exercido apenas na união conjugal, se faz sentir em favor da glória 
do Estado e da felicidade pública. Que homem bárbaro poderia resistir à voz da honra e da razão na boca de uma terna esposa? E quem não desprezaria um luxo vão, vendo vossa aparência simples e modesta que, realçada por vosso brilho, parece ser a mais favorável à beleza? Cabe a vós manter sempre, por vosso amável e inocente império e por vosso espírito insinuante, o amor às leis no estado e a concórdia entre os cidadãos, reunir por acertados casamentos as famílias divididas e principalmente corrigir, pela persuasiva doçura de vossas lições e pela graça modesta de vossa atitude, as extravagâncias que nossos jovens vão buscar em outros países [...] Sede sempre, portanto, as castas guardiãs dos costumes e doces laços da paz, e continuai a fazer valer, em qualquer ocasião, os direito do coração e da natureza em proveito do dever e da virtude" (ROUSSEAU, 2013, p. 420).

Em todo momento, no fragmento acima, se percebe a educação da mulher para a vida conjugal (a mulher faz a felicidade do homem), a clara indicação de que o poder da mulher, aquele que faz com que ela controle sempre o homem está no aparato conjugal, na beleza, na doçura etc. São, para o autor "as guardiãs dos costumes", mostrando que o discurso iluminista excluía a mulher da participação política no Estado, seu "Estado" era, na verdade, a família, e, desta forma, alija a mulher de um aspecto importante para a sua inclusão enquanto pessoa (pessoalização) e enquanto sujeito de direito (personalidade jurídica).

Eis um pequeno retalho ilustrativo e regional do fastigado e longo processo de aquisição de direitos e da personalidade jurídica das mulheres, ainda hoje vivo, com particularidades próprias do nosso tempo.

\subsection{A mulher cidadã: resposta à Constituição Francesa de 1791}

Mais que uma posição enquanto pessoa, a obra de Wollstonecraft pleiteia à mulher a conquista da cidadania, da capacidade política plena e, consequentemente, da possibilidade de participar ativa e passivamente do processo de escolha política de seu tempo. Seu documento oferece uma contraposta a então recente Declaração dos Direitos do Homem e do Cidadão (1791), que, a começar pelo título ${ }^{22}$, não propugnava direitos legiferados às mulheres, não lhes garantia acesso à educação e tampouco a inclusão cidadã na vida pública. Deixa expressas também as fissuras da filosofia iluminista e do Direito Natural ${ }^{23}$, bem como da falseadora

\footnotetext{
22 Salienta-se que o vocábulo Homem não fora utilizado como sinônimo de humanidade, mas como significante de ser humano do sexo masculino.

${ }^{23}$ Há de ser dito que também o direito natural, que então passava pela revisão racionalista, determinante na instituição do conhecido modelo jusracionalista e que represara seu conteúdo na totalidade dos códigos que o séc. XIX, não escapa às críticas e argumentos de Mary Wollstonecraft. Sobre o tema é difícil não lembrar da Tragédia Antígona, de Sófocles. Na obra, escrita por volta de 442 a.C., Antígona é colocada “[...] em cena uma mulher sem
} 
proposição que autores como Rousseau fazem sobre a igualdade de direitos, eis que à metade da população era negada o status de cidadania.

As reinvindicações das mulheres foram anatematizadas e suas porta-vozes perseguidas e ridicularizadas. Olympe de Gouges ${ }^{24}$, por elucidação, contemporânea de Mary Wollstonecraft - que escreveu a "Declaração dos Direitos da Mulher e da Cidadã" em 1791, também em resposta à declaração revolucionária - acabou sendo guilhotinada na França reformadora exatamente por defender os direitos da mulher. Em suas palavras: "Se as mulheres têm direito de subir ao cadafalso e à guilhotina, elas também têm direito de subir à tribuna", ou seja, de possuir direitos políticos e cidadania real (GOUGES, 1986).

Dallari (2004, p. 11), assenta que a Revolução Francesa trouxe à lume a moderna concepção de cidadania, objetivando a eliminação de privilégios, porém "[...] pouco depois, foi utilizada exatamente para garantir a superioridade de novos privilegiados". Essa condição “inatural" foi denunciada por Wollstonecraft que delineou bem o tratamento dessemelhante entre os sexos que negava, às mulheres, os direitos políticos de cidadãs. Sua obra vai contra a lei do povo - ou a lei de poucos, homens, que se diziam ilustrados - em favor da verdadeira

partidários, sem exército, sem armas. Antígona abala a tirania sozinha numa sociedade em que a vida pública era de exclusiva competência masculina" (SCHÜLER, 2007). Trata-se da primeira obra literária da História em que se evoca a noção de direito universal humano. Seria a fase embrionária do princípio da dignidade humana. Na tragédia, Antígona, uma das filhas do rei Édipo, falecido durante um exílio, retorna a sua cidade onde descobre que seus irmãos morreram em guerra fratricida. Ao irmão de Antígona é negado o direito de ter seu corpo enterrado. Antígona confronta o rei fundamentando-se no respeito ao costume sobre o qual as vontades do monarca não poderiam incorrer. Surge, então, em seu clamor, o argumento da lei natural, ao ser questionada sobre o dever da obediência cívico descumprido por ela. Em resposta, aduz: "Sim, pois não foi decisão de Zeus, e a justiça, a deusa que habita com as divindades subterrâneas, jamais estabeleceu tal decreto entre os humanos; tampouco acredito que tua proclamação tenha legitimidade para conferir a um mortal o poder de infringir as leis divinas, nunca escritas, porém irrevogáveis, não existem a partir do ontem ou do hoje, são eternas, sim! E ninguém pode dizer desde quando vigoram! Decretos como o que proclamastes, eu, que não temo o poder de homem algum, posso violar sem merecer a punição dos deuses!" (Sófocles, 2007, p. 63). Desta forma, reverbera e questiona a validade absoluta do direito posto em detrimento ao direito natural, sendo, o primeiro, o pensamento defendido pelo monarca e o segundo, por Antígona. Um embate que aloca o Direito legislado pelo homem e a Justiça; ou o direito que é em face ao direito que deveria ser, em proposição semelhante aos questionamentos de Wollstonecraft sobre como é o tratamento da mulher e como deveria ser.

24 Olympe de Gouges (1748-1793) era francesa - estando sempre no epicentro da revolução. Também se destacou pela pungência dos seus escritos reivindicadores de uma ordem justa compassada com os princípios e ditames iluministas. Em sua "Declaração dos Direitos da Mulher e da Cidadã" (1771), em alva crítica à Declaração dos Direitos do Homem e do Cidadão (1771) e chamamento das mulheres ao revolucionamento, proclama nos primeiros dois artigos de seu manifesto: "Art. $1^{\circ} \mathrm{A}$ Mulher nasce livre e permanece igual ao homem em direitos. As distinções sociais só podem ser fundamentadas no interesse comum. Art. $2^{\circ}$ : O objetivo de toda associação política é a conservação dos direitos naturais e imprescritíveis da Mulher e do Homem. Estes direitos são a liberdade, a propriedade, a segurança, e, sobretudo, a resistência à opressão". 
igualdade de condição, unificada na figura de todos estarem, independentemente do gênero, irmanados na condição de pessoas $^{25}$.

Postergadas da condição de cidadãs, reservadas ao direito da educação que não excede os limites da família, as mulheres estavam automaticamente excluídas da esfera da representação política, não tendo direito, sequer, à representação na Plenária e nas Assembleias. A democracia representativa, as cartas constitucionais exsurgentes, toda a lavra de direitos substanciados pelos novos ideários de liberdade, igualdade e fraternidade - fizeram-se, naquele momento inicial, sob a ausência da figura da mulher, o que denota, em si, explícita incoerência ontológica e deontológica com seus próprios regramentos e princípios.

O novo universo de sujeitos de direitos, igualdados sob a égide de critérios definidos como positivos em oposição-contradição aos socialmente excluídos, "diferentes", "nãosujeitos", sinalizou a tátil supressão de setores sociais - nesse rol as mulheres, determinando "igualdade" equivocada, dissonante, confusa:

Um legislador benevolente deve se esforçar para fazer com que o interesse de cada indivíduo seja resguardado; e assim, a virtude se tornará o cimento da felicidade pública e, de modo ordenado, o todo é consolidado pelo rumo de todas as partes em direção a um centro comum. (WOLLSTONECRAFT, 2016, p.187).

Nesse ínterim, aduz que a "[...] virtude da mulher é capaz de agir pelo mesmo princípio da Razão. Deve metade da raça humana, como os pobres escravos africanos, ficar sujeita a preconceitos que a brutalizam apenas para adoçar a chávena do homem, quando princípios seriam uma proteção mais segura?" (WOLLSTONECRAFT, 2016, p. 188). Esse olhar requalificado impulsiona (ou pretende) desestabilizar os terrenos firmes e consolidados da tradição, causando sismos. Enquanto escritora protofeminista, inegavelmente iniciou,

\footnotetext{
${ }^{25}$ O direito posto, a Constituição Francesa de 1791, à semelhança Declaração dos Direitos do Homem e do Cidadão, não previra em seu bojo a cidadania para as mulheres, pautara-se pela visão parcial do fenômeno ilustrativo que se operava no mundo e, deste modo, deixara o feminino encrustado às margens da Justiça. Consoante os valores dos documentos políticos, a cidadania política era desacorde com as características do sexo feminino. A Revolução acabou legitimando a perpetuação de uma ordem simbólica que impediu qualquer forma de participação verdadeira das mulheres. Na carta a Talleyrand-Périgord giza-se bem essa consciência de exclusão que tem a autora: "Considere tais observações, senhor, de maneira desapaixonada, pois um lampejo dessa verdade pareceu surgir a sua frente quando observou 'que ver metade da raça humana excluída pela outra metade de toda participação no governo era um fenômeno político impossível de explicar de acordo com princípios abstratos'. Se é assim, em que se apoia sua constituição? Se os direitos abstratos do homem sustentarão o debate e a explanação, os da mulher, por analogia, não serão submetidos à mesma análise, embora uma opinião diferente prevaleça neste país, baseada nos muitos argumentos que o senhor utiliza para justificar a opressão da mulher - a prescrição" (WOLLSTONECRAFT, 2016, p. 21).
} 
conjuntamente a outros nomes, a longa caminhada da mulher para firmar-se enquanto sujeito(a) de direitos, titular das relações e de pessoalidade jurídica.

Reivindicou, ainda em meados de 1792, que as mulheres desfrutem de sua razão, vontade e liberdade, delineando e defendendo a noção de autonomia, da universalidade da lei moral e, sobretudo, do conceito de dignidade da pessoa humana.

Como se sabe, sob a salvaguarda dos direitos de personalidade descansa a proteção de direitos ditos irrenunciáveis e intransmissíveis, num liame que vincula necessariamente o reconhecimento da dignidade da pessoa - valor fundante para o desenvolvimento das faculdades-potencialidades humanas. Dessa ordem de proteção despontam três condições precípuas: autonomia, alteridade e dignidade.

Nesse tríplice alicerce, da autonomia, exsurge, como alhures alocado, o respeito à liberdade e ao autogoverno moral de que deve desfrutar toda pessoa humana; na alteridade, configura-se o recorte de ética relacional lastreada no ser-estar dos indivíduos, que age na composição de compromisso transindividual ou metaindividual entre as pessoas sem qualquer distinção; já a dignidade se realiza na conjugação de ambos: necessita que se assegure à pessoa a autonomia da vontade dentro de uma relação ética em que a alteridade é presente. Assim, no rol de direitos da personalidade, assenta-se a métrica de predicados que vão dar garantia à incolumidade físico-psíquica aos direitos invioláveis da liberdade e igualdade.

A exclusão da mulher do rol de direitos criados e das discussões referentes à personalidade jurídica do humano, vai refletir-se, outrossim, na supressão do próprio exercício da cidadania. E as conquistas que se seguiram, certamente inspiradas em manifestos poderosos como o da autora, vieram em passos cambaleantes e lentos. Basta pensar-se que, no campo político, o direito ao voto chegou muito tardiamente. O sufrágio feminino, reivindicado em diferentes partes do mundo, concretizara-se como direito apenas em meados do século XX, dois séculos depois de Mary Wollstonecraft reclamá-lo na Reinvindicação dos direitos da mulher.

Metade da raça humana excluída pela outra metade de toda participação no governo era um fenômeno político impossível de explicar de acordo com princípios abstratos. Se é assim, em que se apoia tal Carta Constitucional? Se os direitos abstratos do homem sustentarão o debate e a explanação, os da mulher, por analogia, não serão submetidos à mesma análise, embora uma opinião diferente prevaleça neste país, baseada nos muitos argumentos que se utilizam para justificar a opressão da mulher. Considere, legislador, se no momento em que os homens lutam por sua liberdade 
e pelo direito de julgar por si mesmos sua própria felicidade, não é inconsistente e injusto subjugar as mulheres, ainda que creia-se firmemente estar-se agindo da melhor maneira para lhes promover bem-estar. (grifo nosso). (WOLLSTONECRAFT, 2016, p.20).

A dignidade, tem-se consciência, com Kant (2007, p. 67-68), consiste no rigoroso respeito ao direito da pessoa de ser fim em si e por si mesma, e em não ser usada por ninguém como meio para outros objetivos. A dignidade do ser humano leva à preservação da vida de uma pessoa em virtude de seu valor ínsito, independentemente de quem ela seja, dos interesses que estejam em jogo, ou das necessidades de quem faz a escolha: a vida deve sempre prevalecer em razão do respeito ao dever de dignificar o semelhante enquanto ser racional e livre que é (LIMA JR, 2013, p. 335), e não do gênero sexual.

Mary Wollstonecraft não deixa de sublinhar as nuances negativas trazidas pelas transformações da Revolução na vida das mulheres, sobretudo na esfera do Direito, eis que estavam privadas, pela nova ordem constitucional, do acesso a direitos fundamentais básicos, vinculados ao princípio da igualdade e da dignidade humana.

Para além do simples aspecto anedótico, reivindica, assim, nova interpretação ao modo como a sociedade compreende o feminino, com a proposição de se inserir, nessa ordem constitucional, esse novo sujeito de direito: a mulher. A Constituição revolucionária não propugnava cidadania às mulheres, negava-lhes o direito ao voto e à representação e denegavalhes o acesso à educação formal, monstrando-se paradoxalmente incongruente aos ideais iluminares de igualdade humana que nortearam sua própria criação e promulgação:

Se as mulheres, pois, devem ser excluídas, sem voz, da participação dos direitos
naturais da humanidade, prove-se antes, para afastar a acusação de injustiça e
inconsistência, que elas são desprovidas da razão e de sua humanidade. De outro
modo, essa falha na Nova Constituição sempre mostrará que o homem deve de alguma
forma agir como um tirano, e a tirania, quando mostra sua face despudorada em
qualquer parte da sociedade, sempre solapa a moralidade. [...] Quando a Constituição
for revisada, espera-se que seja realizada nova interpretação. Pode ser que os Direitos
da Mulher, nessa hora, sejam respeitados, caso seja plenamente provado que a razão
exige, como os ideais de igualdade e dignidade humana. (WOLLSTONECRAFT,
2016, p. 21).

A realidade, repisa-se, é que o manifesto bradou não apenas pelo direito da mulher de acesso aos espaços da vida pública, mas a sua efetiva emancipação por meio de tudo aquilo que aos homens era deferido e, às mulheres, proibido. Constata-se, por fim, que Wollstonecraft tinha consciência de que a Razão e o Direito poderiam socorrer a mulher em seu estado de 
permanente clausura, transformando, mesmo que a passos de tântalo, a mentalidade social que perpetrava essa ordem de injustiças, postura que denota condutas incompatíveis com a dignidade e o valor da pessoa humana. Dito em uma palavra, pugnou o processo de pessoalização ${ }^{26}$ da mulher, numa reinvindicação simultânea do direito à vida, à autonomia, à autodeterminação, - historicamente tutelados pelo patriarcalismo - bem como a transformação da mentalidade social de seu tempo.

\section{CONCLUSÃO}

O fim deste trabalho possibilitou compreender um pequeno retalho na complexa colcha que narra os débitos e problemáticas resultantes do processo de exclusão social da mulher no recorte iluminista e, em especial, cotejando a obra de Wollstonecraft e Rosseau. Reinvindicação dos Direitos da Mulher, de Mary Wollstonecraft, firma-se como importante documento histórico que testemunhou e contribuiu no caminho de emancipação da mulher até alcançar o status pleno de pessoa e de sujeito de direitos (algo ainda em construção no nosso tempo).

Num período histórico de turbulentas transformações, redesenhado pelos ideais do iluminismo e pelas imersões do capitalismo industrial, o manifesto de Wollstonecraft acabou por ressoar avant la lettre, inspirando, ao menos, alguma reflexão sobre os direitos da mulher junto aos seus interlocutores, marcando sua escrita com contornos "protofeministas". É fato constatável no presente trabalho que o pensamento de Wollstonecraft se encaixa no convencional do Iluminismo, mas o é igualmente aferível que o faz sob escrutínio crítico, buscando compreender o caminho de participação de segundo nível destinado ao feminino. Elucida, indubitavelmente, essa pecha como consequência esperada da desigualdade histórica

\footnotetext{
${ }^{26}$ Importa notar que, hoje, compreende-se o processo de pessoalização como um tema que alberga noções que não apenas se apresentam como dados biológicos, mas, sobretudo, como acesso cultural e histórico, tal como sustenta Hogemann (2015, p. 50): "Importante apontar que essa transcendentalidade intrínseca à ideia de pessoa humana para os que diferenciam ser humano de pessoa, não pode ser considerada como uma característica atribuível à 'natureza' humana, mas como resultante de um processo histórico cultural, demarcado por seus componentes de ordem ética e moral. Tanto a consciência quanto a pessoalidade são momentos posteriores e deduzidos pela experiência humana".
} 
e da sistemática denegação da mulher à integração aos espaços de conhecimento, de acesso à educação formal e à Universidade.

O estudo valeu-se, portanto, da crítica esclarecida de Mary Wollstonecraft sobre o discurso racionalista de seu tempo, elegendo como contraposto maior as ideias de Rousseau em três obras: "Emilio ou Da Educação", "Do Contrato Social" e "Discurso sobre a origem e os fundamentos da desigualdade entre os homens". Pensador que, conforme visto, é diretamente contraposto pela autora.

Desse embate de ideias se tentou compreender, em sede de metodologia qualitativa com uso da análise compreensiva da obra e do tempo dos autores, a existência de um momento de libertação da pessoa, no qual se afirma romper com o passado, mas que, ironicamente, se mostra desidioso com a mulher. Em outros termos, nos três âmbitos recortados no estudo - a educação, a pessoalidade e a cidadania - a mulher não é vista com a plena autonomia que o preceito libertário setecentista atribuía às pessoas. Ao contrário, era compreendida, em especial na obra selecionada de Rousseau, como um ser a ser cuidado - tutelado -; biologicamente constituído para cuidar do homem, do lar e das crianças. Um ser cuja graça está na beleza e no sentimento, e não na razão. Essa condição pré-estabelecida não apenas contraria a natureza moral (autônoma, no sentido kantiano) das pessoas, como também diminui sobremaneira a própria pessoalidade da mulher que acaba sendo voz apagada no discurso de seu tempo. Esse alijamento se faz presente no discurso, mas é fortemente compreendido e percebido no modo como deve ser educada (para a casa, o homem e a família), no modo como é tratada como pessoa (carente de tutela) e na forma como a cidadania lhe era negada (era soberana apenas do lar).

\section{REFERÊNCIAS}

ARISTOTELES. Ética a Nicômaco. Tradução, textos adicionais e notas Edson Bini. 4. ed. São Paulo: Edipro, 2014.

ASSIS, Machado. Dom Casmurro. São Paulo: Melhoramentos, 2018 (Arquivo Kindle).

COMTE, Augusto. Catecismo positivista. São Paulo: Nova Cultural, 2000. (Coleção Os Pensadores). 
BELTRÃO, Kaizô Iwakami; ALVES, José Eustáquio Diniz. A reversão do hiato de gênero na educação brasileira no século XX. Cadernos de Pesquisa, v. 39, n. 136, p. 125-156, jan./abr. 2009. Disponível em: http://www.scielo.br/pdf/cp/v39n136/a0739136.pdf. Acesso em: 26 out. 2019.

BERGÈS, Sandrine. The Routledge guidebook to Wollstonecraft's A vindication of the rights of woman. Nova York: Routledge, 2013.

BURNS, Edward McNall. História da civilização ocidental: do homem das cavernas às naves espaciais. São Paulo: Globo, 2005.

DALLARI, D. A. Direitos humanos e cidadania. São Paulo: Moderna, 2004.

DAMIÃO, Abraão Prustelo. O Renascimento e as origens da ciência moderna: Interfaces históricas e epistemológicas. História da Ciência e Ensino: Construindo Interfaces. São Paulo, v.17, pp. 22-49, 2018. Disponível em: https://revistas.pucsp.br/hcensino/article/view/34411. Acesso em: 04 abril 2020.

DECLARAÇÃO UNIVERSAL DOS DIREITOS DO HOMEM (1948). Disponível em: http://unesdoc.unesco.org/images/0013/001394/139423por.pdf. Acesso em: 20 set. 2019.

ESTACHESKI, Dulceli de Lourdes Tonet; MEDEIROS, Talita Gonçalves de. A atualidade da obra de Mary Wollstonecraft. Estudos Feministas, Florianópolis, 25(1), n. 422, jan./abril, 2017. Disponível em: http://www.scielo.br/pdf/ref/v25n1/1806-9584-ref-25-01-00375.pdf. Acesso em: 04 abril 2020.

FERREIRA, M. L. R. As mulheres na filosofia. Lisboa: Edições Colibri, 2009.

GOUGES, Olympe de. Declaração universal dos direitos da mulher. Paris: Éditions Syros, 1981.

Déclaration des Droits de la Femme et de la Citoyenne (1791). In. Euvres. Paris:
$\begin{aligned} & \text { Mercure } \\ & \text { de }\end{aligned}$ France, $1986 . \quad$ Disponível
https://fr.wikisource.org/wiki/D\%C3\%A9claration_des_droits_de_la_femme_et_de_la_
citoyenne. Acesso em: 26 out. 2019.

HEGEL, Georg Wilhelm Friedrich. Introdução à história da filosofia. Lisboa, Edições 70, 2006.

HOBSBAWM, E. J. A era das revoluções. 9. ed. São Paulo: Paz e Terra, 1996.

HOGEMANN, Edna Raquel. Bioética, alteridade e o embrião humano. Rio de Janeiro: Multifoco, 2015.

HORÁCIO. Flacci epistvlarvm liber primvs, 20 a.C. Disponível em: http://www.thelatinlibrary.com/horace/epist1.shtml. Acesso em: 27 out. 2019. 
IBER, Christian. Introdução à filosofia moderna e contemporânea: orientação sobre seus métodos. Porto Alegre: Edipurs, 2012.

JOHNSON, Claudia L (Ed.). The cambridge companion to Mary Wollstonecraft. Nova York: Cambridge University Press, 2002.

LIMA JR, Oswaldo Pereira de. Direito, justiça e ética: qual a moralidade melhor sustenta o direito à vida? Revista Direito \& Paz. Lorena, Ano XV n. 29, pp. 335-368, 2. Semestre de 2013. Disponível em: https://www.academia.edu/2641144/Direito_justi\%C3\%A7a_e_\%C3\%A9tica_qual_moralida de_melhor_sustenta_o_direito_\%C3\%A0_vida. Acesso em 18 set. 2019.

. Bioética, pessoa e o nascituro: dilemas do direito em face da responsabilidade civil do médico. Rio de Janeiro: Multifoco, 2017.

O conto da aia: a (des)pessoalização como dimensão epistêmico-moral fundadora da condição de sujeito de direito da mulher. Anamorphosis - Revista Internacional de Direito e Literatura. Porto Alegre, v. 5, n. 1, pp. 69-93, janeiro-junho 2019. Disponível em: http://seer.rdl.org.br/index.php/anamps/article/view/470. Acesso em: 18 set. 2019.

LISPECTOR, Clarice. Perto do coração selvagem. Rio de Janeiro: Rocco Digital, 2019 (Arquivo Kindle).

KRAMER, Heinrich, SPRENGER, James. O martelo das feiticeiras: malleus maleficarum. 3. ed., Rio de Janeiro: Editora Rosa dos Tempos, 1991.

KANT, Immanuel. Crítica da razão pura. 5. ed. Lisboa: Fundação Calouste Gulbenkian, 2001. Resposta à pergunta: o que é o esclarecimento? Brasília: Casa das Musas, 2008. . Fundamentação da metafísica dos costumes. Lisboa: Edições 70, 2007.

MARCONDES, Danilo. Iniciação à história da filosofia: dos pré-socráticos a Wittgenstein. 9. ed. Rio de Janeiro: Zahar, 2005.

MELLO, Vico Denis S. de; DONATO, Manuella Riane A. O pensamento iluminista e o desencantamento do mundo: modernidade e a revolução francesa como marco paradigmático. Revista Crítica Histórica, Ano 2, n. 4, Dez. 2011. Disponível em: http://200.17.114.107/index.php/criticahistorica/article/view/2776/pdf. Acesso em 05 abril 2020 .

MICHELET, Jules. A feiticeira. Rio de Janeiro: Nova Fronteira, 1992.

MORIN, Edgar. Para além do iluminismo. Revista FAMECOS, Porto Alegre, n. 26, abril 2005. Disponível em: https://www.redalyc.org/pdf/4955/495550182003.pdf. Acesso em 05 abril 2020.

ROUSSEAU, Jean-Jacques. Emílio ou da educação. 2. Ed. São Paulo: Martins Fontes, 1999. 
Do contrato social. São Paulo: Martin Claret, 2006.

. Discurso sobre a origem e os fundamentos da desigualdade entre os homens. Porto Alegre: L\&PM, 2013 (Arquivo Kindle).

SCHÜLER, Donaldo. Apresentação. In: SÓFOCLES. Antígona. São Paulo: Martin Claret, 2007.

SÓFOCLES. Antígona. São Paulo: Martin Claret, 2007.

WOLLSTONECRAFT, Mary. Reivindicação dos direitos das mulheres. São Paulo: Edipro/Boitempo, 2016.

Maria; or, the wrongs of woman. In: Delphi complete works of Mary Wollstonecraft (illustrated). Hastings: Delphi, 2016.

Data de Submissão: 16/03/2020

Data de Aceite: 30/03/2020 